\title{
AN INTEGRATIVE INTERPRETATION OF PERSONAL AND CONTEXTUAL FACTORS OF STUDENTS' RESISTANCE TO ACTIVE LEARNING AND TEACHING STRATEGIES
}

\begin{abstract}
Active Learning is a constructivist approach based on the student-centred teaching perspective, but even though it is a method useful for promoting student engagement, for supporting students in the development of their abilities, for enhancing their reflection on their ways of learning, and for developing autonomous control of their own learning process, students' resistance seems to be a common reaction in the contexts where it is used. The purpose of this paper is to present an integrative interpretation of students' resistance to active learning based on the ways in which students demonstrate their resistance to it, and the strategies that teachers can use to counteract this resistance. Based on this new interpretation, the practical implications are presented: the creation of an ecological didactic system; the importance for teachers to be well prepared for the reasons causing students' resistance and the use of an ecological teaching strategy for overcoming it, a strategy which lets them make reasonable pedagogical choices and avoid giving up on the method's implementation.
\end{abstract}

Keywords: Higher Education, Active Learning, students' resistance, learning strategies, ecosystem learning variable

\section{CELOSTNA INTERPRETACIJA OSEBNIH IN SPREMLJEVALNIH DEJAVNIKOV UPIRANIA ŠTUDENTOV AKTIVNEMU UČENJU IN STRATEGIJE POUČEVANJA - POVZETEK}

Aktivno učenje je konstruktivističen pristop, utemeljen na učni perspektivi, ki je usmerjena na učenca - v našem primeru študenta. Vendar pa se kljub temu, da ta metoda lahko izboljša sodelovanje študentov, jim pomaga pri razvijanju sposobnosti, pri poglabljanju njihovega razmišljanja o lastnih načinih učenja in krepitvi avtonomnega nadzora nad lastnim učnim procesom, študenti nanjo pogosto odzivajo z upiranjem. Cilj tega prispevka je predstaviti celostno interpretacijo upiranja aktivnemu učenju na podlagi tega, kako se pri študentih to upiranje pojavlja, ter tudi strategije, s katerimi lahko učitelji to upiranje preprečijo. Izhajajoč iz te nove interpretacije, so predstavljeni njeni praktični napotki: ustvarjanje

Concetta Tino, PhD, University of Padua, concetta.tino@unipd.it 
ekološkega didaktičnega sistema; pomen tega, da učitelji dobro poznajo razloge študentov za upiranje in so nanje pripravljeni, prav tako pa tudi na uporabo ekološke učne strategije, s katero lahko to upiranje premagajo in ki jim omogoča razumno pedagoško odločanje ter vztrajanje pri uporabi metode aktivnega učenja.

Ključne besede: visokošolsko izobraževanje, aktivno učenje, upiranje študentov, učne strategije, ekosistem kot učna spremenljivka

\section{INTRODUCTION}

In recent decades European policies have enhanced the development of a new scenario aimed at drawing the attention of educational and training professionals to strategies useful for avoiding students' disengagement and drop-outs, guaranteeing the improvement of students' performance (European Higher Education Area [EHEA], 2015; High Level Group on the Modernisation of Higher Education, 2013) by developing skills which allow them to be lifelong learners and active citizens, and face the challenges of changes and globalization processes as well. It is a new perspective on learning that inevitably questions the idea of teaching as a means of transmitting knowledge and where the responsibility for deciding what and how students should learn is the teacher's task.

The current social and individual needs suggest promoting the shift from "teaching as transmission of knowledge" to "teaching as learning facilitation, as meeting students" learning needs" and "facilitating students to become independent learners" (Kember \& Kwan, 2000, p. 484). The aim is to avoid the transmissive nature of traditional teaching, with the idea that a top-down model of building knowledge undermines the creativity, the autonomous and investigative capacity of the learner, and denies the dialogical nature of the teaching and learning process itself (Saltman, 2009).

Teachers' assumptions of learning and teaching have been shown to influence teaching approaches and practices. In fact, on the one hand, teachers who consider teaching as a process for passing information to students use teacher-focused strategies; on the other hand, teachers who perceive teaching as a way to help students develop and change their perspectives and become independent learners implement a student-focused approach (Kember \& Kwan, 2000; Trigwell \& Prosser, 1996). Despite the awareness of the impact teachers' assumptions have on teaching practices and the lack of effectiveness of traditional teaching (Weimer, 2013), approaches based on the student-centred perspective, such as active learning, meet with students' resistance (Borrego, Froyd, \& Hall, 2010; Burger, 2013; Finelli et al., 2014; Froyd, Borrego, Cutler, Henderson, \& Prince, 2013; Henderson \& Dancy, 2009) even if they are recognized as those most suitable for facilitating the cognitive processes of learning as well as the involvement and participation of students. It is precisely in this perspective that this conceptual paper seeks to respond to the following research questions: i) What are the characteristics of students' resistance to active learning? ii) Why do students resist active learning? iii) What strategies can 
teachers use to prevent students' resistance? iv) What is the new interpretation of students' resistance?

\section{ACTIVE LEARNING APPROACH CHARACTERISTICS}

Active Learning is a constructivist approach which allows teachers to create connections between the learning environment and the metacognitive processes of the students by implementing active teaching practices useful for emphasizing critical thinking, to involve students in collaborative activities. It is a perspective that actively involves students in the construction of knowledge and the meanings of the world around them; it allows them to become consciously responsible for their learning, rather than being passive listeners of content provided by the teacher (Blignaut, 2014). In fact, active learning pedagogy is an educational philosophy and practice based on a shared responsibility related to the choice of learning methods, content, and sometimes of assessment procedures. Although this participatory approach is often considered time consuming, it allows students to personalise their own learning paths, avoiding their estrangement from the process of knowledge construction.

Active learning methods require students to be creative and inquiring and involve them in "doing things and thinking about the things they are doing" (Bonwell \& Eison, 1991, p. 2). It is a teaching process that goes beyond basic memorisation, focusing on analysis and examination of course-related concepts, developing students' skills and their self-learning control. In fact, its participatory dimension helps students to "become critical, informed, and autonomous builders and judges of different sophisticated world views" (Mathie, 1993, p. 190). Active learning foresees active teaching: it is a two way-process. In fact, "active learning is not do-it-yourself learning; it must be planned thoroughly by an instructor" (Mathie, 1993, p. 189) even if it typically acknowledges the students' active role in their own learning (Judi \& Sahari, 2013).

Active learning, based on the student-centred perspective, improves the students' learning experience in different ways (Weimer, 2013). Firstly, it engages students in the hard work of learning. For a long time, teachers have recognized students in only passive roles, carrying out too many activities on their behalf, such as asking questions, adding details to their answers, offering examples, organising the contents, making the process revisions. Without having the opportunity to experiment and practice, students cannot develop sophisticated learning skills.

Secondly, it includes explicit skills instructions. In fact, it is an approach which does not take it for granted that students develop skills on their own, but that it is the teacher who explains how to solve problems, evaluate evidence, analyse topics and formulate hypotheses. This will allow students to approach various disciplines as experts.

Thirdly, it encourages students to reflect on what and how they are learning. By guiding them in this process, the teacher challenges their assumptions, encourages them to take responsibility for their learning process and to reflect on their improvement objectives. 
Fourthly, student-centred approaches motivate students by giving them the opportunity to be in control of their learning process thanks to the possibility of participating in the definition of class policies such as what content to discuss, the choice and delivery deadline of tasks, and of contributing to the definition of assessment criteria. All these allow students to live within a democratic learning environment, where there is a balance of power between students and teachers, and where dialogue, common responsibility, discussion and respect for different perspectives become the key dimensions of the class-context.

Fifthly, it encourages collaboration since it aims to develop structures that promote common tasks and objectives, thanks to which learning is pursued individually and collectively. It is a way of developing a learning community where students can learn from, and with, each other.

Indeed, active learning is based on engaging students in activities and creating a classroom environment that allows them to be protagonists in their own learning process. It is consistent with educational approaches based on theories of learning and motivation (Kember, 2016). The following highlights some of them:

- cooperative learning (Johnson, Johnson, \& Smith, 1998), where students work together on problems in a small group allowing all members of the group to understand the problem and complete the task;

- case-based studies (Rybarczyk, Baines, McVey, Thompson, \& Wilkins, 2007), where students apply their knowledge to real-world scenarios, promoting higher levels of cognition;

- problem-based learning (Allen, Duch, \& Groh, 1996), where students work on an undefined scenario often based on a real issue; they actively research the problem and look for solutions with the support of different resources (e.g. literature). Problem-based learning contributes to the development of students' critical thinking, problem solving skills, and the ability to apply their newly learned skills to unfamiliar situations (Hintz, 2005).

Although active learning has the potential to give voice and power to students and generate their positive attitudes towards the learning process (Bonwell \& Elson, 1991), it is an approach that still meets some obstacles during the implementation process: one of them is students' resistance. Focusing on this last aspect, this paper presents how challenging the relationship between students and the active learning approach can be, and what strategies can be used to counteract students' resistance as well.

\section{CHARACTERISTICS OF STUDENTS' RESISTANCE TO ACTIVE LEARNING}

The effectiveness of active learning in improving student learning, compared to the traditional teaching approach, has largely been proven (Freeman et al., 2014; Prince, 2004), but students can have different reactions to teachers' use of new instructional methods; some groups of students respond in a positive way, others in a negative way, showing strong resistance to the new approach (Tolman \& Kremling, 2017). 
Why do students resist active learning? There are different reasons for students' resistance to active learning strategies:

- they can increase the students' workload;

- they can cause anxiety and discomfort concerning the ability required by the performance and the expectations;

- they can require time to learn new skills, focusing students' attention on them instead of on the course content, and giving students the impression of learning less;

- they are based on a self-directed learning attitude, creating a discrepancy between students' expectations and experience. This happens when the new approach requires students to reorient their teaching and learning assumptions.

All this means that the different reactions to active learning can depend on the learning assumptions of students. There are two main conceptions of learning among students, the surface and deep approaches to learning: i) in the surface perspective, learning is mainly reduced to a passive experience for students since it is seen as a way to receive and "absorb" ready-made knowledge, which has been built by the teacher. According to this point of view, learning is perceived as an increase in knowledge, memorisation, reproduction and application of what has been learned; ii) for others learning is a process in which students try to create personal meanings through an active approach to learning (Beaty, Dall'Alba, \& Marton, 1990; Jones \& Kember, 1994). These are two types of beliefs students develop as part of their past learning experience and which inevitably influence the reactions that they have when confronted with unexpected situations, activities, and methods. Therefore, it is on the basis of previous experience that students perceive the level of appropriateness of the current learning experience. Even if the teacher's goal is to promote the students' autonomy and independence by providing good and active learning opportunities as well as the development of new skills, active methods can often disorient students and conflict with their past learning experience or with the values that underpin their teaching assumptions.

A common aim of the active strategies and methods is not just knowledge and repetition of facts, but the facilitation of higher-order thinking skills, understanding, application, analysis, synthesis and evaluation of knowledge (Bloom, Edwards, \& Ghatei, 1984). According to Pascarella and Terenzini (1991), they are skills that require the students to engage with the subject matter, identified as the key component of successful learning in tertiary education. In this sense, active approaches foresee a strong interconnection between knowledge and the knower (Prosser \& Trigwell, 1999), the evidence of which is the students' participation in the activity and their reflection on the experience. It is a process that allows them to internalise knowledge by developing links between their internal structures and the external world. In fact, Gibbs (1988) states: "It is not enough just to do, and neither is it enough just to think. Nor is it enough to simply do and think. Learning from experience must involve linking the doing and the thinking" (p. 9).

According to Kearney, Plax, and Burroughs (1991) the different resistance strategies used by students depend on whether the teacher is perceived as an immediate teacher or 
non-immediate teacher. This means that students select "teacher-owned" strategies when they perceive teachers as the cause of their negative learning experience, recognizing them as "cold, aloof, distant teachers" (p. 10); in contrast, students use "student-owned" strategies when they consider themselves to be responsible for their negative resistance (other priorities, lack of motivation; they make different decisions). Some teachers' misconduct is considered as antecedent of students' resistance, and this mirrors Felder's (2011) statement:

Whenever I've explored this issue with instructors distressed by it, I have invariably found that the teaching method they were trying was not the real problem. It was either that they were making one or more mistakes in implementing the method, or something else was troubling the students and the method was a convenient scapegoat. (p. 132)

Teacher misconduct can be referred to in three dimensions: i) incompetence: teachers show a lack of teaching skills ("teachers rush through materials, make tests too difficult, may fail to recognize the importance of incremental methods of instruction") (Felder, 2011, p. 28); ii) offensiveness: teachers are disrespectful ("teachers humiliate students in front of the class [...]. They use profanity, become angry or yell and scream in their efforts to intimidate students. [...] [They] are rude, self-centered, moody, and whiners; they condescend to students by acting superior and arrogant") (p. 29); iii) indolence: teachers are disorganised ("absent-minded teachers are those who fail to show up for class, are late when they do, and offer poor excuses for their truancy [...] [They] are late in returning students' papers and exams") (p. 30). As reactions to teachers' misconduct Kearney and Plax (1992) have identified 19 students' resistance categories ${ }^{1}$ that Weimer (2013) presents in a simpler way, reducing them to three basic levels:

1. passive, non-verbal,

2. partial compliance, and

3. open resistance.

Students who show passive, nonverbal resistance participate less in class activities; for example, they try to justify not doing assignments or pretend to complete them. Students with partial compliance complete activities without interest, with minimal commitment and at the lowest quality. Open resistance occurs when students openly complain about the teaching methods, and often with the intent of encouraging their classmates to do the same.

Students' resistance is also identified as constructive or destructive behaviour (Kearney \& Plax, 2012; McCroskey \& Richmond, 1992). Constructive behaviour is described as including those student behaviours related to asking challenging questions, suggesting

1 These 19 students' resistance categories are "teacher advice, teacher blame, avoidance, reluctant compliance, active resistance, deception, direct communication, disruption, excuses, ignoring the teacher, priorities, challenge the teachers' basis of power, rally student support, appeal to powerful others, modeling teacher behavior, modeling teacher affect, hostile defensive, student rebuttal, revenge." (Kearney \& Plax, 1992, p. 92) 
corrections, providing spontaneous peer help, submitting constructive feedback for instructor improvement on evaluations, correcting or clarifying interventions or materials provided by the teachers. These are forms of suggestions or recommendations and complaints that may often annoy teachers or be perceived as threats. In reality they provide them with very useful and meaningful feedback on daily activities and teaching processes, guiding them in the improvement of methods and activities, as well as in the formulation of requests and tasks for students. Destructive forms of resistance delimit learning experience for students. The most common forms fit with passive dimensions of resistance (McCroskey \& Richmond, 1992), such as ignoring the teachers or their requests, avoiding participation or sitting in the back, not attending class, interrupting purposefully, or communicating concerns directly to the teachers. These are student actions often connected to their own feelings when they are in the classrooms; they mirror situations in which they feel frustrated or disengaged from the experience they are living. Student misbehaviour can also be caused by social loafing in their interaction with peers, ranging from simple active strategies in pairs, small group discussions, to complex cooperative learning or project work activities, required among students in order to successfully carry out tasks and achieve goals. When this expectation is prevented by poor interaction, it is possible to register the students' resistance. Poor interaction between individuals and their classmates is generated when they are working in a group and their contribution is unbalanced. The low level of participation of social loafers increases the workload of the other members of the group and is considered unequal and unfair, generating students' resistance toward teamwork activities (Pfaff \& Huddleston, 2003).

Students' resistance to active learning can also often be related to the academic learning expectations or the role they are invited to play, without much support by the instructor, in the new learning setting, where it is possible that participants tend to consider their skills and knowledge quite insufficient for performing in a proper way in the new context. In fact, students are often worried about their lack of knowledge in relation to active learning and feel uncomfortable with the prospect of taking responsibility or assessing their own work or that of their peers. Indeed, these are the feelings that can cause a sense of inadequacy and the idea of being in the wrong place. Another aspect related to the issue of new learning settings can be the social relationship. If some students consider group activities as a chance to have further resources for their learning, others can think about the social group as a threat (Burger, 2013). All this makes some students defend themselves from these potential threats by developing self-protecting strategies, which are resistance behaviours. This phenomenon can be strongly connected to an individual's self-efficacy in dealing with new challenges (Bandura, 1982). In fact, the sense of self-efficacy influences people's thinking, feelings, behaviours, and can motivate them or create barriers to taking part in different situations. Therefore, the resistance related to the sense of self-efficacy can be considered as "an attempt of self-protection that results from the complex dynamics of relationships, personal experiences, expectations, and interpretations" (Burger, 2013, p. 7), which prevent students from engaging in an active learning context. 


\section{STRATEGIES FOR PREVENTING STUDENTS' RESISTANCE}

The active learning approach, aimed at enhancing learning and being developmental, can create anxiety, uncertainty, and stress (Reynolds \& Trehan, 2000). It can indeed cause "defensive dynamics that limit learning on a cognitive, emotional, and behavioural level" (Burger, 2013, p. 9), but some strategies can be adopted to counteract and limit students' resistance. In fact, if an individual's sense of self-efficacy is influenced by past experiences, teachers obviously cannot change students' past experiences but they can help them develop a different perspective through which they can reinterpret it (Burger, 2013). In fact, an individual's sense of self-efficacy can be reinforced through the three strategies suggested by Bandura (1982): i) enactive attainment, according to which successful mastery experiences enhance the sense of self-efficacy. This is a way to help students gradually develop their skills for tackling complex tasks by both increasing the complexity of the assignments and splitting them into subtasks. They are strategies which help students to adopt a different perspective for looking at their learning experiences and is strongly connected to active learning; ii) the vicarious experience is another strategy that can support the development of students' sense of self-efficacy. It provides situations in which observing others' successful experience promotes a change in students' perspectives, convincing them of having the same ability to complete that assignment; iii) modelling strategies to confront challenging situations is another way to create a further vicarious experience for students. Active learning activities can be developed in order to create contexts in which students can experiment with successful experiences, observe others in action (vicarious experience), and have some good models for facing threatening situations, developing new ways of interpreting their past and present experiences. In addition to this individual level of empowering students, Burger (2013) underlines the importance of also supporting them from a collective point of view when they consider group activities a threat instead of a resource. Involving students in gaining awareness of resistance through the work of the group is one of the alternatives suggested by Simpson, French, and Vince (2000) in order to tackle this issue.

Some other strategies for reducing the level of students' resistance include:

- immediacy as physical and psychological closeness. It is usually demonstrated not only through non-verbal language such as eye-contact, tone of voice, gestures, walking in the classroom among the students to reduce physical distance, but also by tending to teacher-student relationships, recognition of the students' work, calling students by name, being available to talk with students before and after lessons. These are all behaviours that allow students to perceive the presence of a "warm, approachable and friendly teacher" (Kearney, Plax, \& Burroughs, 1991, p. 10), and this enhances students' interest and commitment in assignments and activities. A high level of immediacy is also correlated with students' motivation, and cognitive and affective learning (Titsworth, 2001; Allen et al., 1996);

- sharing, at the beginning and during the course, the teacher's pedagogical choices with students. This is supported by the creation of a common framework, made of 
a common language, the presentation of strategies and research that highlights the effectiveness of active learning, the involvement of students in reflecting on their way of learning and in establishing expected behaviour during lessons. It is a practice that allows teachers to build a partnership with students based on shared teaching and learning processes, shared lesson plans, and methods that can support them in learning (Seidel \& Tanner, 2013);

- tending to the interaction among students to guarantee equity of the workload. The aim should be to avoid the social loafing phenomenon through effective interaction among students, the creation of small groups, the assignment of projects that do not have high objectives, and the peer assessment process (Aggarwal \& O'Brien, 2008). The small size of groups allows students to work together even beyond the classroom to facilitate the division of labour or the scheduling of times;

- the variety of methods and activities required to respond to the needs of different students. For instance, clickers or reflective writing activities can respond to the needs of introvert students, allowing them to feel in their comfort zone; while group activities or pair discussions can be the favourite activities for extrovert students. If they perceive themselves outside their comfort zone, they tend to resist the proposals made by the teacher, while the variety of methods allows everyone access to the experiences of the class (Seidel \&Tanner, 2013);

- sharing with students the purpose and expectations of the proposed activities (Felder, 2011; Strobel \& van Barneveld, 2009; Wilke, 2003), linked to the achievement of better learning results and the acquisition of skills useful also for the world of work. Informing students about this supports their involvement and their preparation for active learning activities (Nguyen et al, 2017);

- the use of assessment rubrics to guarantee fairness in evaluation procedures and avoid perceptions of "injustice" (Chory-Assad, 2002). The regular use of rubrics with clear assessment criteria help teachers reduce students' resistance levels related to the perception of unfair evaluation. Sharing the evaluation criteria with them even before the task both clarifies the indicators according to which they will be evaluated and the expectations they should aim for;

- providing constant feedback throughout the process, since it supports both the use of the proposed strategies and learning (Bentley, Kennedy, \& Semsar, 2011);

- the alignment of the proposed activities with the assessments (Bentley et al., 2011). Constructive alignment (Biggs, 2003; Borrego \& Cutler, 2010) is considered a process through which students are informed of learning outcomes, and learning activities are closely related to the evaluation practices in order to achieve shared and expected results. This can encourage the achievement of high results by students, making them perceive the usefulness and effectiveness of the method and supporting their motivation;

- the systematic collection of evidence about the students' perspective regarding the learning environment and their experiences within it; this allows the identification of the presence of resistance and the related causes so as to give voice to students' 
thoughts and their problems or frustrations. The collection of students' opinions can be done with specific questions on the effectiveness of a given activity or on the learning environment in general. It can be done in a transparent or anonymous way, using different techniques such as clickers, a minute paper, a reflective journal. Sharing opinions on the learning environment allows the teachers to promote constructive feedback to improve the teaching process, to increase communication with students, and to monitor and reduce resistance levels. It is a practice which helps students to perceive the level to which their teachers are available to them in order to give them a voice and consider their opinions, to understand how it is not easy to respond to everyone's needs in a class, and how the chosen methods are aimed at allowing everyone to have access to the classroom experience (Felder, 2011; Nguyen et al, 2017);

- promoting awareness of the challenges and the advantages of the active learning method by pointing out that it leads to learning where a traditional lesson might fail, but also the difficulties that other students usually experience when using the method (Mohamed, 2008; Yadav, Subedi, Lunderberg, \& Bunting, 2011);

- promoting familiarisation with the method through a slow and constant introduction of active practices, thanks to a daily exposure to them (Carlson \& Winquist, 2011).

All of these strategies represent ways which allow teachers to support students in discovering the effectiveness of the active learning method. It is a process and in order to be successful, it requires constant tutoring, monitoring, sharing, collection of feedback and transparent communication among teachers and students.

\section{IMPLICATIONS FOR PRACTICE}

The aim of Active Learning as a student-centred approach is to develop students' skills in thinking independently and critically, being a self-directed learner with the ability to have control of their learning process. It is recognized as a holistic approach (McConnell et al., 2017) that promotes the long-term acquisition of knowledge, deep involvement, autonomy and independence in the students, as well as increases their motivation to learn (Weimer, 2013) during their life span. Despite this, and the efforts made by the teachers to prepare materials and activities to design their courses and individual lessons, the benefits are not always immediate and automatic, and they risk resistance from the students. According to the literature, the resistance phenomenon in active learning approaches can be caused by different factors: teachers' and students' misbehaviour, students' expectations or students' teaching and learning beliefs, students' sense of self-efficacy or students' idea of group dynamic limits. However, this paper wants to go further than the vision of the students' resistance as a single cause-effect result, but rather as a dependent variable of a wider learning ecosystem where the causes and characteristics of students' resistance are an integrative combination of personal and contextual factors, where the different teaching strategies to reduce students' resistance need to be considered as facets of a polyhedric strategy that enables the creation of an ecological learning environment (Figure 1). Teaching and learning are complex processes that should be developed with consideration 
for the sensitive bioecological system of the classroom, where personal, interpersonal, and contextual factors constantly interact with teaching and learning, and where each new factor can provoke disequilibrium and uncertainty.

Figure 1: An integrative interpretation of students' resistance to active learning: an ecosystem learning variable faced through an ecological teaching strategy

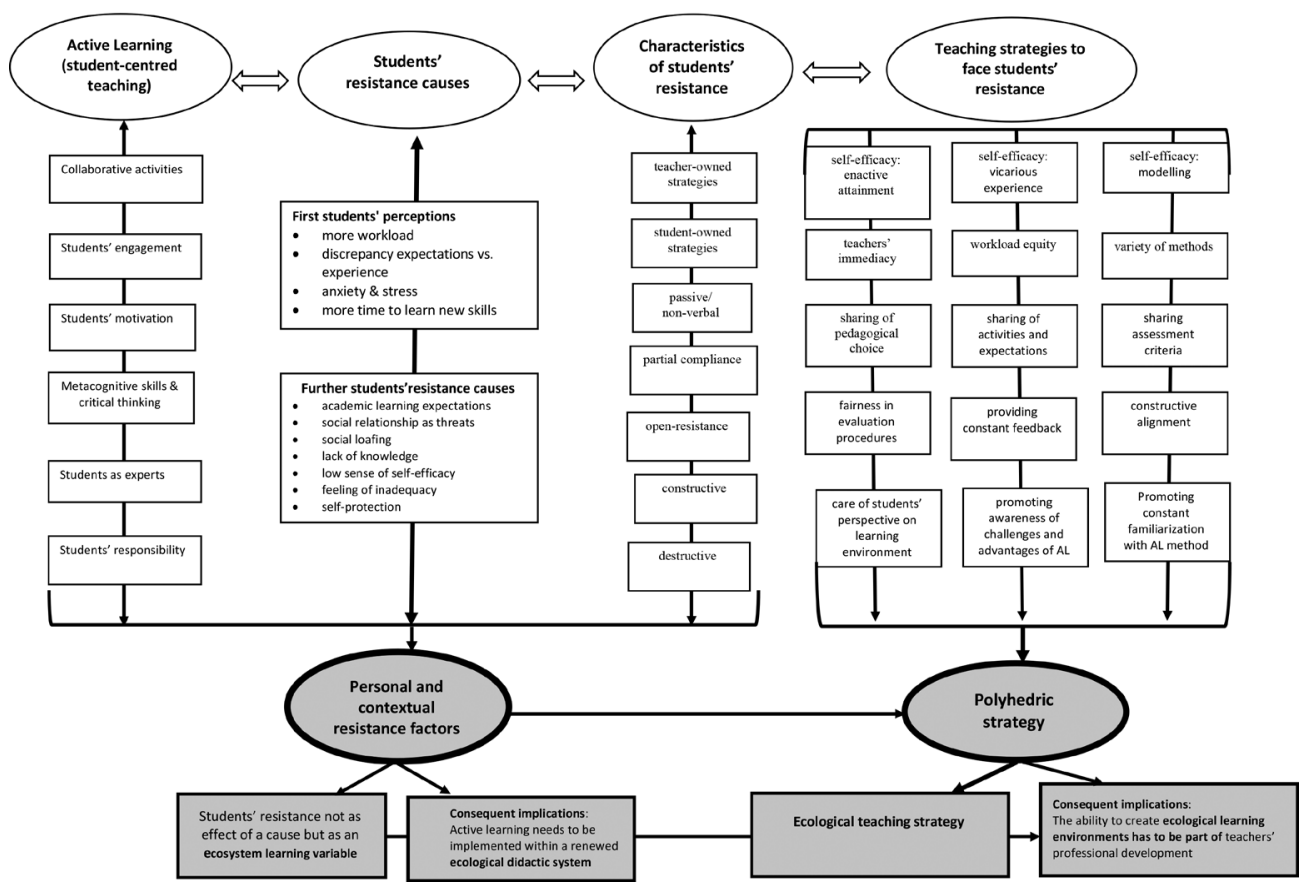

Source: Author's own.

According to Bronfenbrenner's ecological theory (Bronfenbrenner \& Morris, 2006) a system's development is influenced by its interaction with other systems. In the same way the efficacy of a learning context depends on the interaction among its sub-systems: students, teachers, activities, strategies, relationships. Therefore, implementing a new teaching method in the higher education context, where there are often consolidated teaching and learning approaches, requires rethinking the didactic system from an ecological point of view. This enables us to take into account all the dimensions of didactics: relationships, assignments, activities, assessment processes, expectations, beliefs. Consequently, a polyhedric strategy is necessary to re-create a new ecological classroom learning environment and allow each factor to interact in a positive way with the others. This new didactical ecological system generates further implications for teachers' professional development. Changes and the culture of innovation within learning environments need to be built by properly trained "engineers". 


\section{CONCLUSIONS}

In the last decades, many higher education contexts have seen a shift from a traditional and transmissive learning paradigm to a student-centred learning perspective, which has included many teachers introducing active learning activities in their teaching practices, often causing students' resistance. Students' active participation promotes significant learning, and even if teachers meet different forms of students' resistance, it is necessary for them to take a risk, with the awareness that when students are exposed to active learning strategies for the first time, most go through a predictable number of stages: denial, shock and panic, then frustration, and finally acceptance (Felder \& Brent, 1996; Silverthorn, 2006). This therefore requires, on the one hand, awareness of the value of the method, built on participatory teaching and a teacher-student authentic relationship (Cook-Sather, 2002; Cook-Sather \& Luz, 2015; Fedeli, 2017), while on the other hand, knowledge of the possible causes and forms of resistance connected to it, as well as strategies to mitigate them, which can support teachers in making more informed pedagogical choices and motivate them to persist until they get the results connected to authentic student learning.

Of course, being aware of the possibility of encountering challenging situations and having a wide range of strategies teachers can use means that they need to be well prepared in order to implement active learning practices with their students. However, teachers being well prepared would also mean having a thorough knowledge of students' resistance as a dependent variable of a wider learning ecosystem. That would allow teachers to face the challenging management of learning environments not through the use of the strategies implemented in a separated way based on students' reactions, but as a polyhedric strategy useful for tending to the learning environment as an ecosystem, where every new component needs to be introduced well and familiarised with all the others.

The most important reflection for teachers should not be to understand if "active learning is for everyone", but to have a deep knowledge of the phenomenon and to create conditions in which it is possible "to work with and through the action learners' resistances so as to prompt meaningful insights from this experience" (Burger, 2013, p. 8). This means that introducing active learning methods requires skills and reflection from the teachers in order for them to be able to tailor their interventions in the learning ecosystem which their students belong to along with their dynamics, past experiences, and identity, or with their "fight-or-flight attitude"(Burger, 2013, p. 6) that tend to inhibit learning. Reflective practice in action and on action (Shön, 1983) plays the role of a catalyst in improving teachers' skills and competencies, their motivation in implementing active methods, and their critical thinking as well, all of which are useful for creating interventions to counteract students' resistance and create meaningful learning experiences for them.

In conclusion, the paper presented a new interpretation of the nature of students' resistance, one with implications for teaching practices and teachers' professional development. Empirical research is needed to better understand the nature of students' resistance 
as an ecosystem learning variable and the teachers' skills useful in managing an ecological learning environment.

\section{REFERENCES}

Aggarwal, P., \& O’Brien, C. L. (2008). Social loafing on group projects: structural antecedents and effect on student satisfaction. Journal of Marketing Education, 30(3), 255-264.

Allen, D. E., Duch, B. J., \& Groh, S. E. (1996). The power of problem-based learning in teaching introductory science courses. New directions for teaching and learning, 1996(68), 43-52.

Bandura, A. (1982). Self-efficacy Mechanism in Human Agency. American Psychologist, 37(2), 122-147.

Beaty, E., Dall'Alba, G., \& Marton, F. (1990). Conceptions of Academic Learning, Occasional Paper 90.4, ERADU, RMIT, Victoria University of Technology.

Bentley, F. J. B., Kennedy, S., \& Semsar, K. (2011). How not to lose your students with concept maps. Journal of College Science Teaching, 41(1), 61-68.

Biggs, J. (2003). Aligning teaching and assessing to course objectives. Teaching and learning in higher education: New trends and innovations. University of Aveiro 13-17 April, 2003.

Blignaut, S. E. (2014). Reflections on student resistance to a constructivist curriculum. Education as Change, 18(2), 271-283.

Bloom, S. R., Edwards, A. V., \& Ghatei, M. A. (1984). Neuroendocrine responses to stimulation of the splanchnic nerves in bursts in the conscious adrenalectomized calf. Journal of Physiology, 346(1), 519-531.

Bonwell, C. C., \& Eison, J. A. (1991). Active Learning: Creating Excitement in the Classroom. 1991 ASHE-ERIC Higher Education Reports. ERIC Clearinghouse on Higher Education, The George Washington University.

Borrego, M., \& Cutler, S. (2010). Constructive alignment of interdisciplinary graduate curriculum in engineering and science: An analysis of successful IGERT proposals. Journal of Engineering Education, 99(4), 355-369.

Borrego, M., Froyd, J. E., \& Hall, T. S. (2010). Diffusion of engineering education innovations: A survey of awareness and adoption rates in U.S. engineering departments. Journal of Engineering Education, 99(3), 185-207.

Bronfenbrenner, U., \& Morris, P. A. (2006). The bioecological model of human development. In W. Damon \& R. M. Lerner (Eds.), Handbook of child psychology: Theoretical models of child development (6th ed., pp. 793-828) (Vol.1). New York, NY: Wiley.

Burger, U. (2013). Resistance in action learning: struggling with self-efficacy and the social self-and what about the set advisor? Action Learning: Research and Practice, 10(3), 264-275.

Carlson, K., \& Winquist, J. (2011). Evaluating an active learning approach to teaching introductory statistics: A classroom workbook approach. Journal of Statistics Education, 19(1), 1-23.

Chory-Assad, R. M. (2002). Classroom justice: Perceptions of fairness as a predictor of student motivation, learning, and aggression. Communication Quarterly, 50(1), 58-77.

Cook-Sather, A. (2002). Authorizing students' perspectives: Toward trust, dialogue, and change in education. Educational Researcher, 31(4), 3-14.

Cook-Sather, A., \& Luz, A. (2015). Greater engagement in and responsibility for learning: What happens when students cross the threshold of student-faculty partnership. Higher Education Research \& Development, 34(6), 1097-1109. 
European Higher Education Area. (2015). Yerevan Communiqué. Yerevan.

Felder, R. M. (2011). Hang in there! Dealing with student resistance to learner-centered teaching. Chemical Engineering Education 45(2), 131-132.

Felder, R. M., \& Brent, R. (1996). Navigating the bumpy road to student-centered instruction. College teaching, 44(2), 43-47.

Fedeli, M. (2017). Student-faculty partnership: The European framework and the experience of the Italian project employability \& competences. Teaching and Learning Together in Higher Education, 1(20), 2-6.

Finelli, C. J., Nguyen, K., DeMonbrun, M., Borrego, M., Prince, M., Husman, J., ... Waters, C. K. (2018). Reducing student resistance to active learning: Strategies for instructors. Journal of College Science Teaching, 47(5), 80-91.

Freeman, S., Eddy, S. L., McDonough, M., Smith, M. K., Okoroafor, N., Jordt, H., \& Wenderoth, M. P. (2014). Active learning increases student performance in science, engineering, and mathematics. Proceedings of the National Academy of Sciences, 111(23), 8410-8415.

Froyd, J., Borrego, M., Cutler, S., Henderson, C., \& Prince, M. (2013). Estimates of use of research-based instructional strategies in core electrical or computer engineering courses. IEEE Transactions on Education, 56(1), 393-399.

Gibbs, G. (1988). Learning by Doing: A Guide to Teaching and Learning Methods. London, UK: Further Education Unit.

Henderson, C., \& Dancy, M. H. (2009). The impact of physics education research on the teaching of introductory quantitative physics in the United States. Physical Review Special Topics: Physics Education Research, 5(2), 020107.

High Level Group on the Modernisation of Higher Education. (2013). Report to the European Commission on improving the quality of teaching and learning in Europe's higher education institutions. Brussels: Publications Office of the European Union.

Hintz, M. M. (2005). Can problem-based learning address content and process? Biochemistry and Molecular Biology Education, 33(5), 363-368.

Johnson, D. W., Johnson, R., \& Smith, K. (1998). Active learning: cooperation in the college classroom. Edina, MN: Interaction Book.

Jones, A., \& Kember, D. (1994). Approaches to learning and student acceptance of self-study packages. Educational and Training Technology International, 31(2), 93-97.

Judi, H. M., \& Sahari, N. (2013). Student-centered learning in statistics: Analysis of systematic review. Procedia-Social and Behavioral Sciences, 103(2013), 844-851.

Kearney, P., \& Plax, T. G. (1992). Student resistance to control. In V. P. Richmond \& J. C. McCroskey (Eds.), Power in the classroom: Communication, control, and concern (pp. 85-100). New York: Routledge.

Kearny, P., \& Plax, T. G. (2012). Students resistance to Control. In V. P. Richmond \& J. C. McCroskey (Eds.), Power in the classroom: Communication, control, and concern (pp. 85-101). Routledge.

Kearney, P., Plax, T. G., \& Burroughs, N. F. (1991). An attributional analysis of college students' resistance decisions. Communication Education 40(4), 325-342.

Kember, D. (2016). Motivating Students through Teaching and Learning. In D. Kember (Ed.), Understanding the Nature of Motivation and Motivating Students through Teaching and Learning in Higher Education (pp. 79-97). Singapore: Springer.

Kember, D., \& Kwan, K. (2000). Lecturers' approaches to teaching and their relationship to conceptions of good teaching. Instructional Science, 28(5/6), 469-490. 
Mathie, V. A. (1993). Promoting active learning in Psychology course. In T. V. McGovern (Ed.), Handbook for enhancing undergraduate education in psychology (pp.183-214). Washington, DC: American Psychological Association.

McConnell, D. A., Chapman, L., Czajka, C. D., Jones, J. P., Ryker, K. D., \& Wiggen, J. (2017). Instructional utility and learning efficacy of common active learning strategies. Journal of Geoscience Education, 65(4), 604-625.

McCroskey, J. C., \& Richmond, V. P. (1992). Increasing teacher influence through immediacy. In V. P. Richmond \& J. C. McCroskey (Eds.), Power in the classroom: Communication, control, and concern (pp.101-119). Hillsdale, NJ: Lawrence Erlbaum.

Mohamed, A. R. (2008). Effects of Active Learning Variants on Student Performance and Learning Perceptions. International Journal for the Scholarship of Teaching and Learning, 2(2), 1-16.

Nguyen, K., Husman, J., Waters, C., Henderson, C., Finelli, C. J., Demonbrun, M., ... Borrego, M. (2017). Students' expectations, types of instruction, and instructor strategies predicting student response to active learning. The International journal of engineering education, 33(1), 2-18.

Pascarella, E. T., \& Terenzini, P. T. (1991). How college affects students: Findings and insights from twenty years of research. San Francisco, CA: Jossey-Bass Inc.

Pfaff, E., \& Huddleston, P. (2003). Does it matter if I hate teamwork? What impacts student attitudes toward teamwork. Journal of Marketing Education 25(1), 37-45.

Prince, M. (2004). Does Active Learning Work? A Review of the Research. Journal of Engineering Education, 93(3), 223-231.

Prosser, M., \& Trigwell, K. (1999). Understanding learning and teaching: The experience in higher education. UK: McGraw-Hill Education.

Reynolds, M., \& Trehan, K. (2000). Assessment: A Critical Perspective. Studies in Higher Education 25(3), 267-278.

Rybarczyk, B., Baines, A., McVey, M., Thompson, J., \& Wilkins, H. (2007). A case-based approach increases student learning outcomes and comprehension of cellular respiration concepts. Biochemistry and Molecular Biology Education, 35(3), 181-186.

Saltman, K. J. (2009). Historical and theoretical perspectives. In W. Ayers, T. Quinn, \& D. Stovall (Eds.), Handbook of social justice in education, (pp.1-3). New York: Routledge.

Seidel, S. B., \& Tanner, K. D. (2013). What if students revolt? Considering student resistance: Origins, options, and opportunities for investigation. CBE-Life Sciences Education, 12(4), 586-595.

Shön, D. (1983). The reflective practitioner. How professionals think in action. London: Temple Smith.

Silverthorn, D. U. (2006). Teaching and learning in the interactive classroom. Advances in Physiology Education, 30(4), 135-140.

Simpson, P., French, R., \& Vince, R. (2000). The Upside from the Downside: How Utilizing Defensive Dynamics Can Support Learning in Groups. Management Learning 31(4), 457-470.

Strobel, J., \& van Barneveld, A. (2009). Is PBL effective? A meta-synthesis of meta-analyses comparing problem-based learning to conventional classroom learning. Interdisciplinary Journal of Problem Based Learning, 3(1), 44-58.

Titsworth, B. S. (2001). The effects of teacher immediacy, use of organizational lecture cues, and students' notetaking on cognitive learning. Communication education, 50(4), $283-297$.

Tolman, A. O., \& Kremling, J. (2017). Why Students Resist Learning: A Practical Model for Understanding and Helping Students. Sterling, VA: Stylus Publishing.

Trigwell, K., \& Prosser, M. (1996). Changing approaches to teaching: a relational perspective. Studies in Higher Education, 21(3), 275-284. 
Weimer, M. (2002). Learner-centered teaching: Five key changes to practice. John Wiley \& Sons.

Weimer, M. (2013). Learner-Centered Teaching: Five Key Changes to Practice. San Francisco: Jossey-Bass.

Wilke, R. R. (2003). The effect of active learning on student characteristics in a human physiology course for nonmajors. Advances in Physiology Education, 27(4), 207-220.

Yadav, A., Subedi, D., Lunderberg, M., \& Bunting, C. (2011). Problem based learning: Influence on students' learning in an electrical engineering course. Journal of Engineering Education, 100(2), 253-280. 